\title{
VALIDASI PROTOKOL SKRINING VIRTUAL DAN ANALISIS INTERAKSI INHIBITOR ANTIPROLIFERASI SEL KANKER BERBASIS BAHAN ALAM TERHADAP RESEPTOR CYCLIN- DEPENDENT KINASE 4 (CDK 4)
}

\author{
VALIDATION OF VIRTUAL SCREEN PROTOCOLS AND ANALYSIS OF INHIBITOR \\ ANTIPROLIFERATION OF CANCER CELLS BASED ON NATURAL MATERIALS ON
}

CYCLIN-DEPENDENT KINASE 4 RECEPTOR (CDK 4)

\author{
Rizky Arcinthya Rachmania \\ Program Studi Farmasi, Fakultas Farmasi dan Sains \\ Universitas Muhammadiyah Prof. Dr. HAMKA \\ Islamic Center, Jl. Delima II/IV Perumnas Klender \\ Jakarta Timur, 13460, Telp. (021) 8611070 \\ *Penulis korepondensi, email: arcinthya.rizky@gmail.com
}

\begin{abstract}
ABSTRAK
Salah satu target untuk menghambat penyebaran penyakit kanker adalah dengan menghambat proses proliferasi sel kanker yaitu dengan menghambat pengatur aktivitas siklus sel kanker Cyclin dependent kinase 4 (CDK4). Hingga saat ini, struktur kristal CDK4 belum tersedia. Struktur CDK4 yang mirip CDK2 belum tervalidasi terhadap inhibitor ligan native inhibitor reseptor CDK4, sehingga virtual skrining untuk menemukan senyawa bahan alam untuk menghambat proliferasi sel kanker masih belum valid dalam pemakaian struktur kristal CDK4 dan sulit dilakukan pengembangan inhibitor CDK4. Penelitian ini bertujuan untuk memvalidasi metode protokol skrining terhadap struktur CDK4 mirip CDK2 agar dapat digunakan sebagai struktur kristal dalam pengembangan inhibitor CDK4 dan melakukan virtual skrining senyawa bahan alam yang berpotensi sebagai inhibitor CDK4 sebagai antiproliferasi sel kanker. Metode yang digunakan untuk validasi protokol skrining virtual dengan cara redocking. Struktur kristal CDK4 mirip enzim CDK2 dengan kode PDB ID 1GII, $1 \mathrm{GIH}$, dan 1GIJ akan diredocking dan pengamatan validasi berdasarkan nilai Root Mean Square Deviation (RMSD) < 2 A, sehingga protokol skrining yang di kembangkan ini diterima dan dapat dikembangkan untuk penelitian lebih lanjut untuk skrining virtual dalam usaha penemuan senyawa baru inhibitor antiproliferasi CDK4. Setelah itu dilakukan virtual skrining dan analisis interaksi antara 16 senyawa bahan alam dengan reseptor hasil validasi. Hasil validasi metode protokol skrining terhadap struktur CDK4 mirip CDK2 secara internal yang diterima yaitu reseptor $1 \mathrm{GIH}$ dengan ligand native 1PU dan RMSD 0,8072 A. Virtual skrining dan analisis dari 16 senyawa bahan alam yang memiliki skor CHEMPLP terendah yaitu Naringin dengan skor CHEMPLP sebesar -94,1781 Kkal/mol yang jauh lebih baik dibandingkan senyawa pembanding flavopiridol namun masih lebih baik senyawa pembanding abemaciclib, ribociclib dan palbociclib. Interaksi ligand-reseptor pada naringin lebih didominasi oleh ikatan Hidrogen dibandingkan dengan senyawa pembanding abemaciclib, ribociclib dan palbociclib yang didominasi oleh interaksi hidrofobik, sehingga Naringin berpotensi sebagai inhibitor CDK4 sebagai antiproliferasi sel kanker.
\end{abstract}



Kata Kunci : validasi, sel kanker, anttiproliferasi, CDK4

\section{ABSTRACT}

One of the targets to inhibit the spread of cancer is by inhibiting the cancer cell proliferation process by inhibiting the activity regulator of the Cyclin dependent kinase 4 (CDK4) cancer cell cycle. Until now, the CDK4 crystal structure is not yet available. CDK2-like CDK4 structure has not been validated against the ligand inhibitor of native CDK4 receptor, so that virtual screening to find natural material compounds to inhibit cancer cell proliferation is still not valid in the use of CDK4 crystal structure and difficult to develop CDK4 inhibitors. This study aims to validate the screening protocol method for CDK2-like CDK4 structures so that it can be used as a crystal structure in the development of CDK4 inhibitors and conduct virtual screening of natural material compounds that have the potential as CDK4 inhibitors as antiproliferation of cancer cells. The method used to validate virtual screening protocols by means of redocking. Crystal structure of CDK4 similar to CDK2 enzyme with $1 G I I, 1 G I H$, and 1GIJ PDB codes were redone and validation observations based on Root Mean Square Deviation (RMSD) value $<2 \AA$, so that the developed screening protocol is accepted and can be developed for further research on the plate virtual in the effort to discover the new compound antiproliferation inhibitor CDK4. After that, virtual screening and interaction analysis between 16 natural material compounds and validated receptors will be carried out. Validation results of the screening protocol method for CDK2-like CDK2 structures internally received were 1 GIH receptors with $1 P U$ native ligand and RMSD $0.8072 \AA$. Virtual screening and analysis of 16 natural compounds that had the lowest CHEMPLP score was Naringin with a CHEMPLP score of -94,1781 Kcal / mol which was much better than the flavopiridol comparison compound but still better compared Abemaciclib, Ribociclib and Palbociclib. The interaction of ligand-receptors on Naringin is dominated by Hydrogen bonds compared to the comparative compounds abemaciclib, ribociclib and palbociclib which are dominated by hydrophobic interactions, so naringin has the potential as a CDK4 inhibitor as an antiproliferation of cancer cells.

Keywords: validation, cancer cells, antiproliferation, $C D K 4$

\section{PENDAHULUAN}

Kanker merupakan sekelompok penyakit yang ditandai oleh pertumbuhan sel yang tidak terkendali dan penyebaran sel yang abnormal. Jika penyebaran tidak terkendali maka dapat menyebabkan kematian. Penyakit kanker merupakan salah satu penyebab kematian utama di seluruh dunia. Pada tahun 2012, sekitar 8,2 juta kematian disebabkan oleh kanker. Lebih dari $60 \%$ kasus baru dan sekitar 70\% kematian akibat kanker di dunia setiap tahunnya terjadi di Afrika, Asia dan Amerika Tengah dan Selatan. Diperkirakan kasus kanker tahunan akan meningkat dari 14 juta pada 2012 menjadi 22 juta dalam dua dekade berikutnya (Kemenkes, 2015).

Suatu pendekatan baru dilakukan untuk membatasi efek samping dan meningkatkan efektivitas kemoterapi kanker yaitu dengan menggunakan jenis obat yang dapat bekerja terhadap molekul target. Obat-obat ini mampu membunuh sel-sel kanker dengan menghambat atau memutus jalur atau proses tertentu yang penting untuk pertumbuhan dan perkembangan kanker, salah satu jalur yang dimaksud adalah proliferasi kanker yang berkaitan dengan 
interaksi reseptor tertentu. CDK (Cyclin Dependent Kinase) memainkan peranan penting dalam siklus sel dan penting sebagai target obat antikanker. CDK merupakan sekelompok protein kinase yang mengatur tahap-tahap berbeda dalam siklus sel eukariot. CDK juga terlibat pada saat kontrol transkripsi gen, yaitu proses yang mengintegrasi sinyal ekstraseluler dan intrasesuller untuk koordinasi respon siklus sel terhadap perubahan lingkungan dan apoptosis. Aktivasi CDK biasanya terjadi melalui fosforilasi residu treonin spesifik oleh enzim pengaktivasi CDK kinase dan pengikatan terhadap protein cyclin . CDK4 memiliki peranan penting dalam regulasi sel fase G0-G1 dan dibutuhkan pada fase transisi G1/S (Shafiq, Steinbrecher, \& Schmid, 2012).

Flavoviridol yaitu suatu alkaloid flavonoidal semisintetis, muncul sebagai inhibitor CDK pertama yang memasuki fase klinikal trial. Data praklinis menunjukkan bahwa flavoviridol dapat menghalangi proliferasi sel neoplastik dan menginduksi program kematian sel (apoptosis) sebagai senyawa tunggal (Wang and Ren, 2010). Namun sebagai generasi pertama inhibitor CDK4 dan CDK6, flaviridol secara uji klinis memiliki kekurangan yaitu kurang selektif terhadap target (Corona and Generali, 2018). Sehingga dikembangkan senyawa obat lainnya seperti Dinaciclib sebagai generasi kedua inhibitor CDK namun masih memiliki toksisitas yang buruk (Corona and Generali, 2018). Generasi terakhir inhibitor CDK, disamping memiliki keuntungan secara administrasi oral, juga menunjukkan selektivitas yang lebih tinggi, secara spesifik target CDK4 dan CDK6. Tiga senyawa, palbociclib (PD 0332991; Pfizer, Inc.), ribociclib (LEE011; Novartis International AG) dan abemaciclib (LY2835219; Eli Lilly and Company) menjalani uji praklinis dan klinis dan baru-baru ini diijinkan untuk digunakan pengobatan atau metastasis reseptor positif hormon/HER2 kanker payudara (Corona and Generali, 2018). Namun obat-obatan generasi terakhir tersebut riboclib, palbociclib dan abemaciclib juga masih memiliki kekurangan yaitu dapat menimbulkan efek samping seperti diare, toksisitas hematologi, neutropenia, trombositopenia, emboli paru, hyponatremia dan peningkatan kreatinin (Sherr, Beach, and Shapiro, 2016).

Besarnya efek samping obat sintetik pada pengobatan kanker menjadi latar belakang munculnya berbagai penelitian untuk mencari alternatif obat antikanker yang berasal dari herbal, yang diketahui memiliki efek samping yang lebih kecil (Mas'ula \& Kusuma, 2018). Efek samping dan toksisitas obat sintetik yang merugikan menjadi latar belakang banyaknya penelitian yang dilakukan untuk mencari obat antikanker dengan efek samping yang relatif lebih kecil. Herbal telah banyak digunakan di negara-negara Asia sebagai alternatif pengobatan berbagai penyakit kanker mulai dari terapi obat, terapi bedah hingga radioterapi (Mas'ula and Kusuma, 2018). Senyawa-senyawa alami yang berasal dari tanaman, mikroorganisme, dan sejumlah spesies laut memiliki peranan penting dalam penemuan senyawa baru dalam bidang pengobatan seperti pengobatan antikanker. Saat ini lebih dari $60 \%$ senyawa antikanker berasal dari turunan senyawa bahan alam yang memiliki potensi sebagai "lead compounds". Beberapa senyawa bahan alam yang memiliki khasiat sebagai antiproliferasi dari CDK yaitu acetylbritanillakton, apigenin, berberine, dineolignan, epigallocatechin 3 gallat, fangchinoline, indole-3 carbinol, proanthocyanidins, quercetine, rosa Multic Acid, silibinin, wogonin, linarin, tangeretin Daidzein, naringin (Bailon-Moscoso et al., 2017), namun dari senyawa-senyawa tersebut belum diketahui senyawa mana yang memiliki interaksi terbaik dengan reseptor CDK4.

Penemuan senyawa anti proliferasi sel kanker baru membutuhkan waktu yang lama, mahal dan proses yang berisiko. Akan tetapi kemajuan ilmu kimia komputasi dan biologi menimbulkan paradigma baru yang mengijinkan peneliti-peneliti memodelkan dan memahami 
bahwa target obat dan penemuan obat menjadi lebih murah dan aman daripada obat-obatan yang ada dalam rentang waktu yang lama (Syahputra et al., 2014). Ketersediaan struktur kristal protein target memungkinkan penggunaan teknik desain obat berbasis struktur.

Sampai saat ini, struktur kristal CDK4 belum tersedia. Struktur CDK4 yang mirip CDK2 belum tervalidasi terhadap inhibitor ligan native inhibitor reseptor CDK4, sehingga virtual skrining untuk menemukan senyawa bahan alam untuk menghambat proliferasi sel kanker masih belum valid dalam pemakaian struktur kristal CDK4 dan sulit dilakukan pengembangan inhibitor CDK4.Validasi protokol yang dilakukan adalah dengan melihat kemampuan protokol untuk mereproduksi pose ligan native ko-kristal di dalam protein target CDK4. Secara obyektif, kemampuan mereproduksi ini dilihat dari nilai RMSD (Root Mean Square Deviation) antara pose ligan hasil docking dengan pose ligan pada kristal struktur yang dihitung dan divisualisasikan atau superpose (Mumpuni et al., 2014). Pandrangi (2014) telah melakukan studi in silico molecular docking terhadap CDK4 dalam penemuan inhibitor CDK4, namun tidak dilakukan validasi protokol docking terhadap ligan native ko-kristal dari reseptor CDK4 sehingga belum pasti metode virtual skrining dapat diterima karena tidak adanya parameter RMSD dari metode tersebut.

CDK (CDK2, CDK4 dll) yaitu memiliki struktur yang homolog. CDK4, merupakan salah satu CDK yaitu target yang menarik untuk pengembangan novel agen antikanker, namun sulit untuk menemukan inhibitor CDK4-spesifik. CDK2 khususnya memiliki homologi struktural tinggi dengan keluarga CDK. Pada penelitian Ikuta et al. (2001) belum dilakukan mana struktur CDK2 yang mirip CDK4 yang belum divalidasi terhadap kompleksnya sehingga virtual skrining yang dilakukan oleh penelitian sebelumnya masih belum valid dalam pemakaian struktur kristal CDK sehingga sangat sulit dilakukan pengembangan inhibitor CDK4. Penelitian ini bertujuan untuk memvalidasi metode protokol skrining terhadap struktur CDK4 mirip CDK2 agar dapat digunakan sebagai struktur kristal dalam pengembangan inhibitor CDK4 dan melakukan virtual skrining senyawa bahan alam yang berpotensi sebagai inhibitor CDK4 sebagai antiproliferasi sel kanker. Pada penelitian ini dengan menggunakan perangkat molecular modelling, validasi protokol skrining virtual terhadap struktur kristal CDK4 mirip enzim CDK2 dengan PDB ID 1GII, 1GIH, dan 1GIJ (Ikuta et al., 2001) akan dilakukan berdasarkan nilai Root Mean Square Deviation (RMSD) yang kurang dari $2 \AA$. Sebuah protokol diterima bila RMSD heavy atoms hasil docking dibandingkan referensinya kurang dari 2 A (Purnomo, 2013). Jadi protokol yang dikembangkan ini diterima dan dapat dikembangkan untuk penelitian lebih lanjut untuk skrining virtual dalam usaha penemuan senyawa baru inhibitor antiproliferasi CDK4.

\section{METODE PENELITIAN}

Alat dan Bahan

Alat yang digunakan dalam penelitian ini yaitu berupa perangkat keras dan lunak komputer. Komputer dengan spesifikasi AMD Quad Core FX-8800P Radeon R7 up to 3.4 $\mathrm{MHz} 12$ Compute Cores 4C+8G, 4 GB of RAM sistem operasi Microsoft Windows 10 Professional 64-bit dan Linux 16 LTS serta terhubung dengan internet.

Program molecular docking ini bekerja di LINUX dengan system UBUNTU 16 dengan 64 bit. Perancangan ligan dan visualisasi di lakukan melalui Operating System Windows 10. Software yang digunakan yaitu PLANTS 1.2 (http://www.tcd.unikonstanz.de/research/plants.php) yang digunakan untuk docking, YASARA 17.4.17 (http://www.yasara.org/viewdl.htm) yang digunakan untuk preparasi protein dan visualisasi, 
Marvinsketch 17.9.0 (http://www.chemaxon.com/marvin/download-user.html) yang digunakan untuk preparasi ligand dan Molegro Molecular Viewer 2.5 yang digunakan untuk visualisasi.

Struktur 3D CDK4 analog CDK2 yaitu 1GII, 1GIJ dan 1GIH diunduh dari Protein Data Bank dengan situs http://www.rcsb.org/pdb yang berformat .pdb. Sebelumnya, reseptor yang akan digunakan dilihat pada jurnal yang akan digunakan sebagai bahan acuan. Struktur 3D ligan yang digunakan adalah flavoviridol, abemaciclib, palbociclib dan senyawa bahan alam acetylbritanillakton, apigenin, berberine, dineolignan, epigallocatechin 3 gallat, fangchinoline, indole-3 Carbinol, proanthocyanidins, quercetine, rosa Multic Acid, Silibinin, Wogonin, Linarin, Tangeretin Daidzein, naringin yang diunduh dari www. pubchem.ncbi.nlm.nih.gov.

Jalannya Penelitian

Penyiapan struktur protein

Pengunduhan makromolekul siklooksigenase-1 dari Protein Data Bank dengan situs http://www.rcsb.org/pdb. Makromolekul protein yang dipilih adalah CDK4 analog CDK2 pada manusia dengan format .pdb (Ikuta et al., 2001). Makromolekul protein dipisahkan dari pelarut dan ligan atau residu non standar. Pemisahan makromolekul dari molekul yang tidak di perlukan dilakukan dengan menggunakan program YASARA (edit $>$ delete $>$ residu). Dihilangkan water(edit > delete > water) dan ditambahkan hidrogen pada struktur(edit > add $>$ hidrogen to all). Hasil tersebut disimpan dengan nama protein dalam format .mol2.

Preparasi struktur ligan

Struktur ligan dalam bentuk 2D dapat diunduh pada situs www. pubchem.ncbi.nlm.nih.gov . Protonasi dilakukan pada pH 7,4 menggunakan software Marvin Sketch (Calculation > Protonation > Major Microspecies), data yang didapat disimpan dengan format .mrv. Pencarian konformasi dilakukan dengan software yang sama (Calculation > Conformation > Conformer) lalu file disimpan dengan format. mol2.

Validasi Metode Molecular Docking

Validasi protokol dilakukan untuk menentukan nilai root mean square distance (RMSD). Validasi menggunakan program YASARA (Analyze > RMSD > Molecule) dengan memasukkan ligan spesifik dan reseptor dengan format .mol2. Sebuah protokol diterima apabila RMSD heavy atom sebesar kurang dari $2.0 \AA$.

\section{Molecular Docking dengan PLANTS 1.2}

Docking dilakukan pada sistem operasi Linux karena Program PLANTS dengan memindahkan semua data dan aplikasi PLANTS. Perintah "cp /home/desktop/PLANTS1.2 PLANTS" setelah itu dimasukkan perintah "chmod $u+x$ PLANTS" untuk mengaktifkan aplikasi PLANTS. Hasil dipindahkan dalam format .mol2 kedalam root dengan perintah "cp /home/desktop/*.mol2."

Pencarian binding site didapat dengan perintah “./PLANTS --mode bind ref_ligand.mol2 5 protein.mol2". Setelah pengaturan sudah benar dimasukkan perintah “./PLANTS --mode screen plantsconfig" ditunggu hingga proses docking selesai. Hasil docking dengan dapat dilihat pada terminal dengan memasukkan perintah "cd results/" dilanjutkan dengan "more 
bestranking.csv" pilih dari 10 konformasi mana yang lebih kecil nilainya dan hasilnya disimpan dengan perintah “cp *_entry_(nomer konformasi)_conf_01.mol2 /home/desktop/".

Analisis dan Visualisasi Molecular Docking

Hasil docking dapat dilihat pada output dalam format notepad. Penentuan konformasi kompleks hasil docking dilakukan dengan memilih konformasi yang memilih skor CHEMPLP paling rendah. Hasil docking divisualisasi menggunakan software Discovery Studio untuk melihat jarak ikatan hidrogen $<3,5 \AA$.

\section{HASIL DAN PEMBAHASAN}

Tahap awal pada proses docking adalah penyiapan struktur protein, pemilihan protein pada situs PDB didasarkan pada protein yang ingin diujikan. Reseptor CDK4 dalam format .pdb diunduh dari database protein Research Collaboratory for Structural Bioinformatics (RCSB) yang diakses melalui situs http://www.rcsb.org/. Protein yang dipilih untuk CDK4 adalah reseptor yang sudah terkompleks dengan inhibitor sebagai ligan asli. Pengunduhan struktur kristal CDK4 mirip enzim CDK2 dengan PDB ID 1GII, 1GIH, dan 1GIJ (Ikuta et al., 2001) dilakukan. Kode PDB tersebut merupakan kompleks enzim golongan transferase CDK4 dengan inhibitor 1PU dan 2PU yang merupakan inhibitor CDK4 dan juga sebagai ligan asli, yang diperoleh dari fraksinasi oleh X-Ray kristalografi dari Homo sapiens. Struktur protein yang diunduh dari PDB umumnya memiliki struktur protein yang masih mengandung pelarut (air), dan residu lainnya pada proses preparasi akan diperoleh struktur protein tanpa ligan asli dan struktur ligan asli. Struktur protein yang diperoleh adalah protein yang telah kehilangan ligan asli, molekul lain seperti air serta atom-atom tunggal lainnya, sehingga pada proses docking yang berinteraksi hanya senyawa uji dengan protein (Kitchen et al., 2004). Ligan dan molekul air ini harus dihilangkan dari makromolekul protein karena dapat memperpanjang durasi simulasi docking. Penambahan atom hidrogen yang dimaksud adalah memunculkan atom hidrogen yang ada pada struktur sehingga terlihat secara tiga dimensi yang berperan dalam interaksi dengan ligan. Simulasi docking semua proses penyiapan struktur makromolekul protein menggunakan software YASARA.

Proses selanjutnya dalam validasi protokol adalah secara simultan melakukan validasi dasar simulasi docking. Validasi dasar dan standar dari simulasi docking molekul dilakukan dengan melihat kemampuan simulasi untuk mereproduksi pose ligan ko-kristal dalam protein target. Fungsi objektif yang umumnya digunakan menilai kemampuan ini adalah RMSD (Root Mean Square Deviation). RMSD menggambarkan penyimpangan (deviasi) jarak pose hasil docking dibandingkan dengan pose 3D dari ligan target (struktur kode PDB) yang dihitung dan divisualisasikan dengan menggunakan YASARA. Pada proses ini dilakukan optimasi dengan pengulangan (iterasi) sebanyak 10 kali yang memungkinkan untuk memperoleh nilai RMSD sekecil mungkin. Semakin banyak pengulangan semakin mungkin diperoleh nilai RMSD paling minimal. Untuk mendapatkan suatu protokol SBVS yang valid, simulasi docking harus menghasilkan nilai RMSD kurang atau sama dengan 2,0. Dari ketiga kode PDB tersebut terbukti jika semakin tinggi nilai resolusinya semakin besar ruang untuk mereproduksi pose dan struktur ligan ko-kristal. Protokol default merupakan protokol dengan pengaturan umum tanpa penambahan nilai lebih bila ada interaksi antara Ho (hidrogen) dengan suatu asam amino.

Validasi metode docking pada penelitian ini dilakukan dengan me-redocking ligan asli atau ligan native pada kelompok protein yang diunduh dari situs PDB (Protein Data Bank). 
Untuk evaluasi validasi, parameter yang dilihat adalah RMSD dan pose secara visual (Moitessier et al., 2008). RMSD merupakan pengukuran dua pose dengan membandingkan posisi atom antara struktur eksperimental dengan struktur yang di docking atau yang di prediksi (Hawkins et al., 2008) nilai RMSD < 2,0 ̊ biasanya digunakan sebagai kriteria kesuksesan metode docking (Jain and Nicholls, 2008; Moitessier et al., 2008). Semakin nilai RMSD mendekati nol maka pose salinan ligan asli dengan copy ligand semakin mirip. Hal ini menunjukkan protokol yang dikembangkan diterima dan dapat dikembangkan lebih lanjut untuk skrining virtual dalam usaha penemuan senyawa baru (Purnomo, 2011). Visualisasi pose validasi antara ligan asli dengan ligand copy menunjukan bahwa struktur dua molekul memiliki kemiripan posisi dan sudut dari setiap atomnya. Pada RMSD >2,0 $\AA$ akan terlihat dua molekul yang berbeda secara signifikan jika dilihat dari sudut dan posisinya, meskipun memiliki jumlah atom yang sama.

Dari hasil 10 kali iterasi untuk 1GIH diperoleh nilai maksimal RMSD dari 0,8072 hingga nilai minimal 0,63682 $\AA$ (Tabel I). Visualisasi superpose validasi ligan asli (hijau) dengan ligan copy (biru) 1GIH dipilih berdasarkan nilai skor CHEMPLP terendah dengan nilai $-94,9042 \mathrm{Kkal} / \mathrm{mol}$ dan hasil superpose dengan RMSD 0,8072 А (Gambar 1). Hal ini menunjukkan bahwa benar algoritma yang digunakan deterministik dan terdapat banyaknya kemungkinan pose ikatan senyawa ko-kristal dalam loka aktif CDK4 (Gambar 2).

Tabel I. Hasil validasi konformasi 1GIH

\begin{tabular}{ccc}
\hline Score ChemPLP & Konformasi & RMSD $(\AA)$ \\
\hline-93.4142 & 1 & 0.6368 \\
-91.8305 & 2 & 0.7218 \\
-93.6366 & 3 & 0.6460 \\
-92.2982 & 4 & 0.7144 \\
-94.2203 & 5 & 0.7669 \\
-94.3845 & 6 & 0.8304 \\
-93.435 & 7 & 0.8071 \\
-94.5537 & 8 & 0.8895 \\
$\mathbf{- 9 4 . 4 0 6 8}$ & 9 & 0.7688 \\
$\mathbf{- 9 4 . 9 0 4 2}$ & $\mathbf{1 0}$ & $\mathbf{0 . 8 0 7 2}$ \\
\hline
\end{tabular}

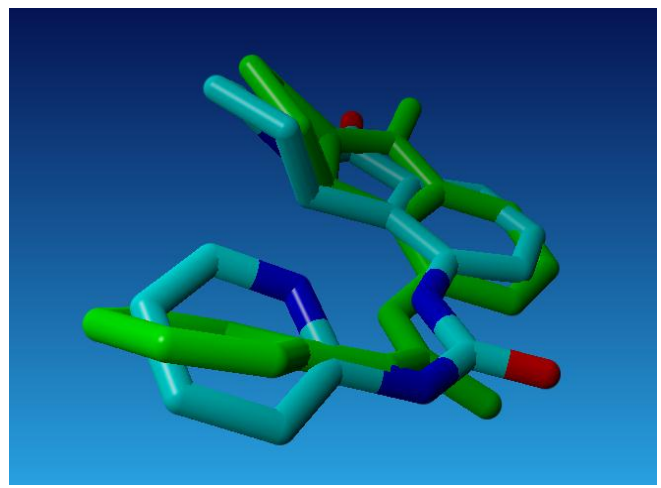

Gambar 1. Visualisasi Superpose Validasi Ligan asli (hijau) dengan Ligan Copy (biru) Menggunakan Software YASARA untuk $1 \mathrm{GIH}$ 


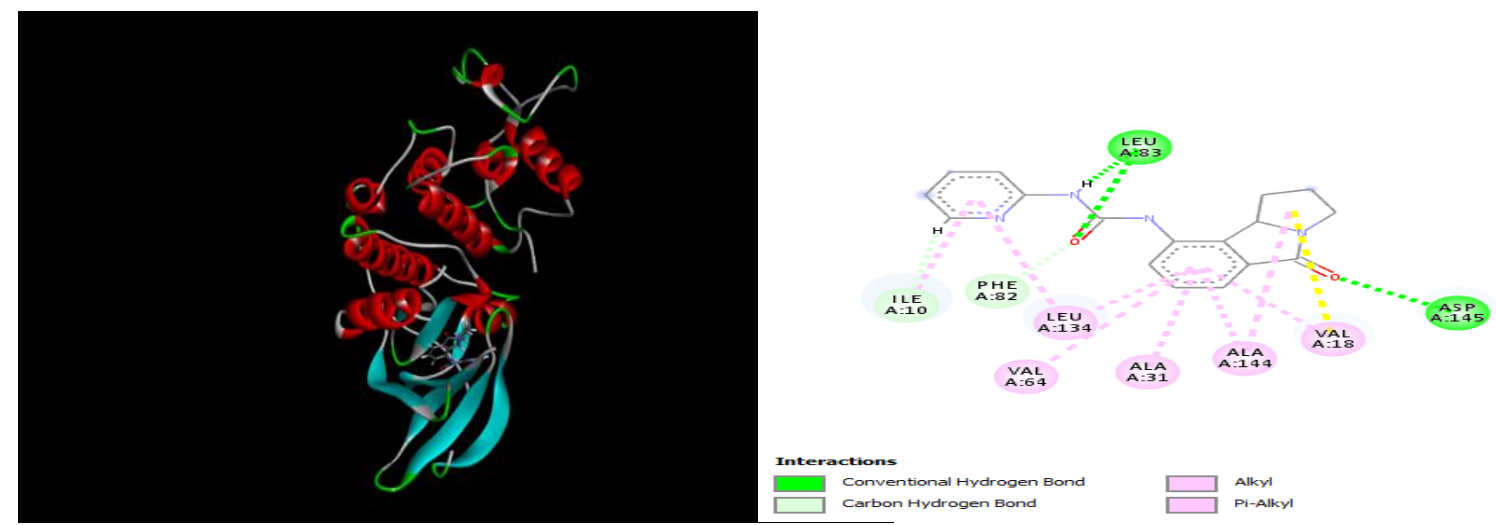

Gambar 2. Interaksi 3D dan 2D kompleks ligan asli dan reseptor GIH pada RMSD 0,8072

Tabel II dan III menjelaskan bahwa ligan ko-kristal hasil docking molekul menduduki loka aktif yang berbeda dengan ligan ko-kristal dari struktur 1GII dan 1GIJ. Hal ini dikarenakan loka aktif dari struktur CDK4 relatif luas sehingga menyebabkan ligan ko-kristal hasil docking molekul mempunyai peluang untuk menduduki bagian-bagian loka aktif yang berbeda dari ligan ko-kristal struktur CDK4 (kode PDB 1GII dan 1GIJ) (Gambar 3 dan 4). Hal ini menunjukkan bahwa protokol tersebut tidak mampu mendudukan sebuah inhibitor CDK4 (dalam hal ini senyawa ko-kristal) pada loka aktif CDK4 dengan akurat. Oleh karena itu protokol tersebut dapat dikatakan tidak valid berdasarkan Tabel IV. RMSD 1GII dan 1GIJ > $2.0 \AA$ dan tidak dilanjutkan ke tahap selanjutnya yaitu virtual skrining. Nilai minimal RMSD untuk kristal struktur COX-2 kode PDB 1GIH dibawah $2 \AA /<2,0 \AA$, maka dinyatakan valid dan dilanjutkan ke tahap selanjutnya yaitu virtual skrining.

Tabel II. Hasil validasi konformasi 1GII

\begin{tabular}{ccc}
\hline Score ChemPLP & Konformasi & RMSD $(\mathbf{\AA})$ \\
\hline-82.7991 & 1 & 5.5046 \\
-81.446 & 2 & 6.0837 \\
$\mathbf{- 8 4 . 5 6 2 7}$ & $\mathbf{3}$ & $\mathbf{5 . 4 5 6 5}$ \\
-83.4639 & 4 & 6.1138 \\
-81.6113 & 5 & 5.9777 \\
-83.2112 & 6 & 5.8341 \\
-82.6072 & 7 & 6.1583 \\
-83.8728 & 8 & 6.1081 \\
-83.1157 & 9 & 6.1489 \\
-82.6069 & 10 & 6.0732 \\
\hline
\end{tabular}


Tabel III. Hasil validasi konformasi 1GIJ

\begin{tabular}{ccc}
\hline Energi & Konformasi & RMSD $(\stackrel{\AA}{\mathbf{A}})$ \\
\hline-98.6047 & 1 & 4.1953 \\
-100.586 & 2 & 1.2513 \\
-101 & 3 & 1.2900 \\
-98.6795 & 4 & 2.8843 \\
-96.5371 & 5 & 1.5023 \\
-96.1562 & 6 & 1.4631 \\
$\mathbf{- 1 0 2 . 4 5}$ & $\mathbf{7}$ & $\mathbf{5 . 4 0 4 0}$ \\
-101.951 & 8 & 1.2628 \\
-101.886 & 9 & 1.2449 \\
-101.821 & 10 & 1.2746 \\
\hline
\end{tabular}
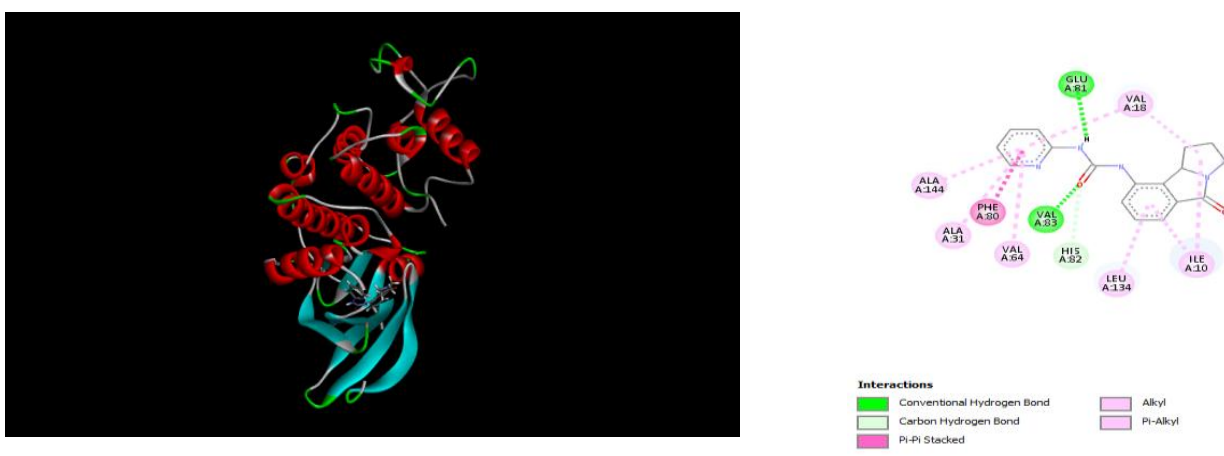

Gambar 3. Interaksi kompleks 3D dan 2D ligan asli dan reseptor GII pada RMSD 5,4565 A
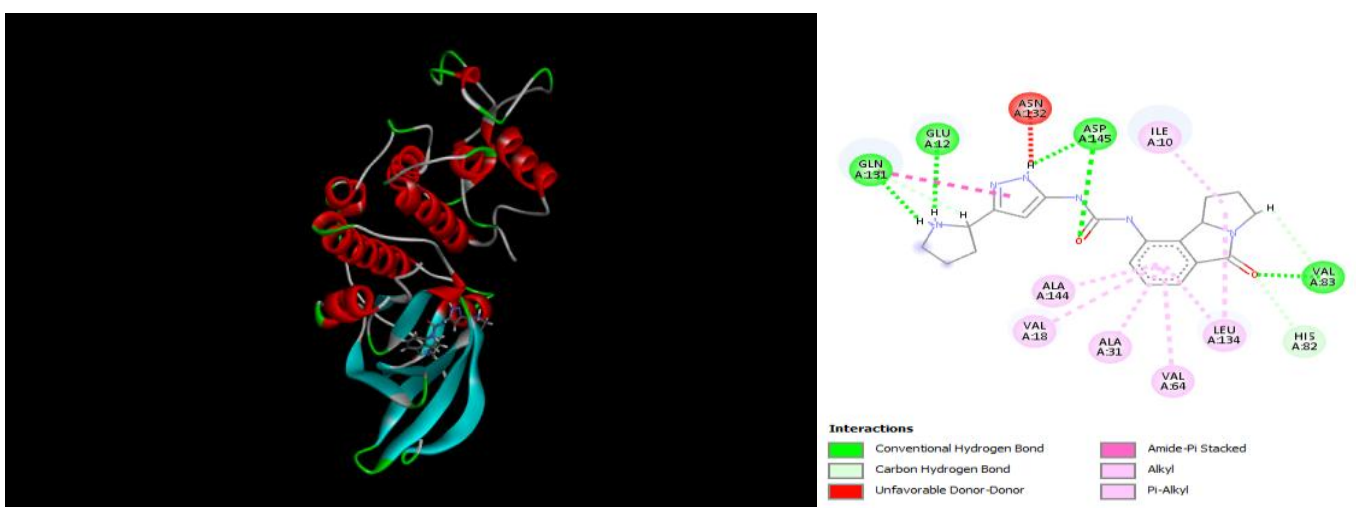

Gambar 4. Interaksi 3D dan 2D kompleks ligan asli dan reseptor GIJ 5,4040 А

RMSD internal juga dapat dapat dikaji juga dari segi skor CHEMPLP masing-masing hasil dari redocking pada tiap konformer untuk 10 kali iterasi yang dilihat dari nilai RMSD internal pada 10 konformer. Pada redocking 1GII (Tabel II) dan 1GIJ (Tabel III) tiap-tiap konformer pada ligan native bersifat tidak stabil, hal ini dapat dilihat dari RMSD hasil superpose bahwa terdapat nilai RMSD dibawah $2 \AA$ dan adapula yang yang diatas $2 \AA$. Hal inilah yang menyebabkan protokol $1 \mathrm{GII}$ dan $1 \mathrm{GIJ}$ tidak valid. Pada redocking $1 \mathrm{GIH}$ dengan ligan native memiliki nilai RMSD hasil superpose yang stabil dibawah $2 \AA$ pada 10 konformasi (Tabel I), hal ini menunjukkan bahwa 1GIH memiliki kestabilan pada tiap-tiap 
konformer dan ligan native stabil pada tiap konformer dan dinyatakan valid atau protokol $1 \mathrm{GIH}$ dapat dilanjutkan ke tahap selanjutnya.

Virtual screening dengan molecular docking bertujuan untuk penapisan senyawa yang memiliki afinitas paling baik dengan mengetahui orientasi antara senyawa atau ligan terhadap reseptor CDK4 untuk membentuk ikatan yang stabil. Adapun parameter kestabilan yang ditentukan adalah energi bebas Gibbs $(\Delta \mathrm{G})$ yang dalam software PLANTS disebut score ChemPLP dan interaksi ikatan kimia yang terbentuk. Docking merupakan pendekatan untuk desain rasional obat menggunakan komputasi untuk menguji aktivitas biologis suatu senyawa. (Giraldo et al, 2007, Reddy et al., 2007). Molecular Docking banyak digunakan untuk memprediksi apakah suatu senyawa memiliki aktivitas atau tidak, serta dapat berguna dalam pengembangan senyawa dengan aktivitas yang lebih baik. Kode reseptor yang digunakan harus sudah tervalidasi secara internal dengan nilai RMSD $<2,0 \AA$ hal ini menunjukkan protokol yang dikembangkan diterima dan dapat dikembangkan lebih lanjut untuk skrining virtual dalam usaha penemuan senyawa baru. Proses docking, memerlukan ligan senyawa alkaloid dalam format.mol2 yaitu ligan yang sudah diminimasi di marvin sketch sehingga akan menghasilkan 10 konformasi bentuk 3D dengan energi bebas yang berbeda.

Satu kali proses docking akan menghasilkan sepuluh konformasi terbaik ligan dari kompleks protein-ligan yang kemungkinan terjadi. Sepuluh konformasi tersebut dipilih konformasi yang memiliki skor CHEMPLP yang terkecil. Skor CHEMPLP yang dihasilkan pada saat kompleks protein-ligan terbentuk dapat menunjukkan afinitas dari ligan terhadap reseptor. Semakin tinggi afinitas dari suatu ligan terhadap protein, maka skor CHEMPLP akan semakin kecil, sebaliknya apabila skor CHEMPLP semakin besar maka afinitas semakin kecil. Tabel IV adalah nilai skor CHEMPLP dari masing-masing ligan terhadap protein CDK4 sebagai reseptor.

Hasil docking yang memprediksi interaksi ligan asli, ligan pembanding yaitu flavoviridol, abemaciclib, ribociclib dan palbociclib dan ligan dari senyawa bahan alam yaitu acetykbritannillacton, apigenin, berberine, dineolignan, epigallocatechin-3-gallate, fangchinolline, indole-3-carbinol, proanthocyanidins, quercetine, rosa multic acid, silibinin, wogonin, linarin, tangeretin, daidzein, naringin dapat dilihat pada Tabel IV, V, dapat diketahui bahwa nilai skor CHEMPLP, senyawa dineolignan memiliki skor CHEMPLP terbesar atau dikatan Dineolignan tidak stabil. silibinin, epigallocatechin-3-gallate dan Apigenin memiliki skor CHEMPLP yang sebanding dengan flavopiridol, namun masih lebih tidak stabil dibanding Naringin yang memiliki skor lebih rendah dibandingkan silibinin, Epigallocatechin3-gallate dan apigenin. Naringin memiliki skor CHEMPLP -94,1781 Kkal/mol hampir sama dengan ligan asli inhibitor CDK4 1PU yaitu -94,9042 Kkal/mol. Nilai skor CHEMPLP Naringin jauh lebih rendah dibandingkan dengan ligan pembanding flavopiridol yaitu $86,6979 \mathrm{Kkal} / \mathrm{mol}$, karena makin kecil skor suatu hasil docking berarti komplek protein-ligan makin stabil sehingga ligan senyawa makin poten (Purnomo 2013), sehingga bila dibandingkan antara Naringin dengan flavopiridol maka Naringin lebih stabil dibandingkan Flavopiridol. Jika naringin dibandingkan dengan pembanding lainnya yaitu abemaciclib, ribociclib dan palbociclib maka nilai skor CHEMPLP Naringin lebih besar sehingga pembanding abemaciclib, ribociclib dan palbociclib jauh lebih stabil dibandingkan naringin. 
Tabel IV. Hasil virtual screening dengan molecular docking menggunakan software plants

\begin{tabular}{ccc}
\hline & Ligan & $\begin{array}{c}\text { Skor } \\
\text { CHEMPLP } \\
\text { (Kkal/mol) }\end{array}$ \\
\hline Ligan Asli & & $-94,9042$ \\
Ligan Pembanding & FlPU & $-86,6979$ \\
Ligan Pembanding & Abemaciclib & $-118,3590$ \\
Ligan Pembanding & Ribociclib & $-111,0300$ \\
Ligan Pembanding & Palbociclib & $-103,7640$ \\
Ligan 1 & Acetylbritannillacton & $-82,5776$ \\
Ligan 2 & Apigenin & $-86,8872$ \\
Ligan 3 & Berberine & $-71,9474$ \\
Ligan 4 & Dineolignan & 18,9316 \\
Ligan 5 & Epigallocatechin-3-gallate & $-88,7392$ \\
Ligan 6 & Fangchinolline & $-60,2847$ \\
Ligan 7 & Indole-3-carbinol & $-62,3561$ \\
Ligan 8 & Proanthocyanidins & $-37,2504$ \\
Ligan 9 & Quercetine & $-78,8998$ \\
Ligan 10 & Rosa Multic Acid & $-64,9919$ \\
Ligan 11 & Silibinin & $-85,8393$ \\
Ligan 12 & Wogonin & $-74,5005$ \\
Ligan 13 & Linarin & $-82,9952$ \\
Ligan 14 & Tangeretin & $-26,2571$ \\
Ligan 15 & Daidzein & $-78,1410$ \\
Ligan 16 & Naringin & $-94,1781$ \\
\hline & & \\
\hline & & \\
\hline
\end{tabular}

Berdasarkan Tabel V dapat diartikan bahwa naringin dibandingkan dengan flavopiridol mempunyai ikatan yang lebih stabil dan afinitas yang lebih baik terhadap reseptor CDK4 namun masih lebih baik obat sintesis sebagai pembandingnya yaitu abemaciclib, ribociclib dan palbociclib, sedangkan ligan lainnya termasuk epigallocatechin-3-gallate dan apigenin memiliki ikatan yang kurang stabil dengan reseptor CDK4 jika dibandingkan dengan naringin. Hal ini menunjukkan naringin memiliki afinitas lebih baik daripada senyawa bahan alam lainnya.

Tabel V. Hasil validasi internal RMSD berdasarkan konformasi dengan score ChemPLP terendah

\begin{tabular}{cc}
\hline Kode PDB CDK4 & Nilai RMSD Protokol Default \\
\hline 1 GIH & $0,8072 \AA$ \\
1 GIJ & $5,4565 \AA$ \\
$1 G I J$ & $5,4040 \AA$ \\
\hline
\end{tabular}


Interaksi reseptor dengan ligan yang terbentuk setelah proses docking divisualisasikan dengan menggunakan software Discovery Studio. Garis-garis putus mendeksripsikan ikatan atau interaksi yang terjadi pada ligan dan reseptor. Pengamatan interaksi residu (asam amino) bertujuan untuk mengidentifikasi interaksi yang terjadi antara ligan dan reseptor. Interaksi ikatan tersebut yaitu berupa ikatan hidrogen, interaksi elektrostatik, interaksi hidrofobik, halogen dan interaksi van der walls (Rollando, 2017).
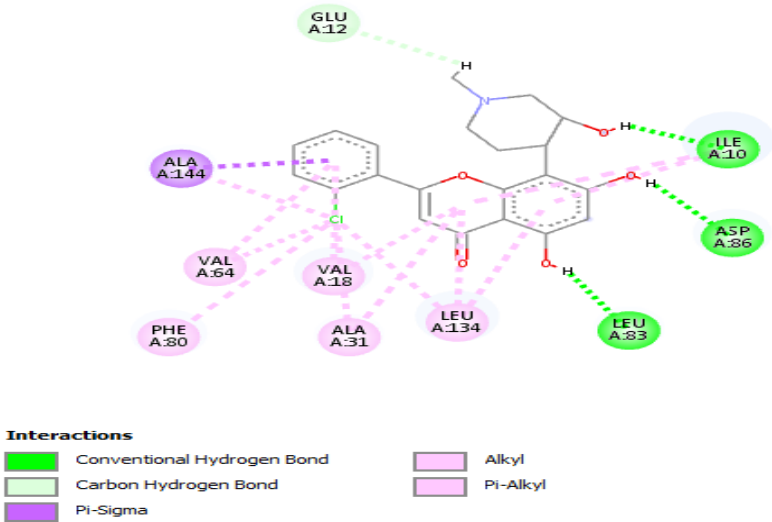

Gambar 5. Visualisasi interaksi senyawa flavopiridol
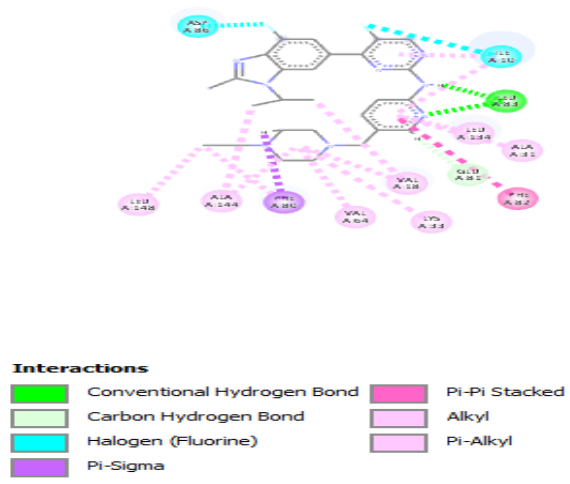

Gambar 6. Visualisasi interaksi senyawa abemaciclib 


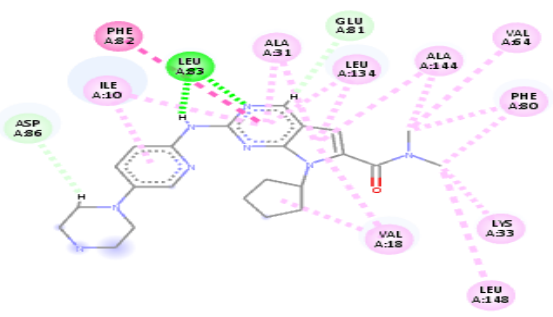

Interactions

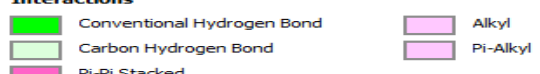

Gambar 7. Visualisasi interaksi senyawa ribociclib

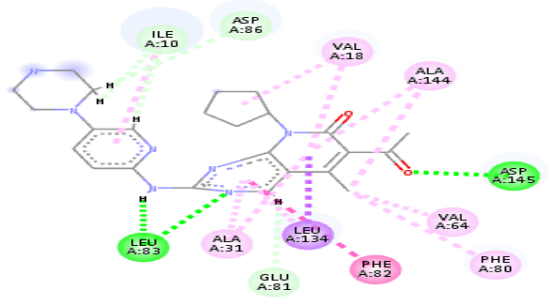

Interactions

Conventional Hydrogen Bond

Carbon Hydrogen Band

Gambar 8. Visualisasi interaksi senyawa palbociclib
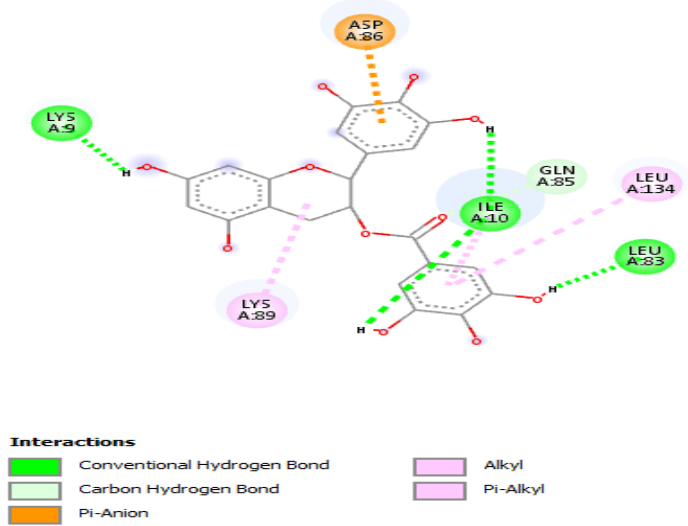

Gambar 9. Visualisasi interaksi senyawa epigallocathecin 3 gallate 


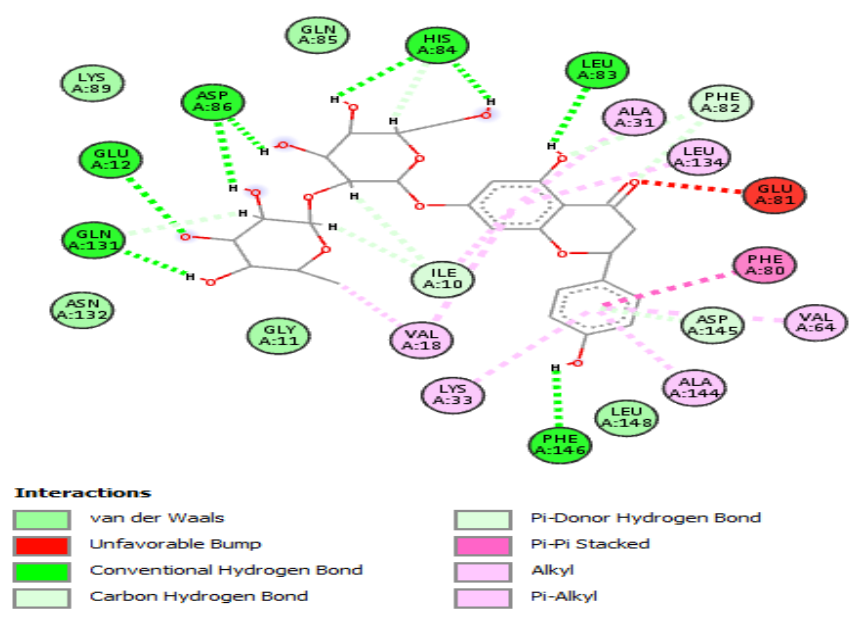

Gambar 10. Visualisasi interaksi senyawa naringin

Gambar 5, 6, 7, 8, 9, 10 dapat dilihat perbandingan residu dari 3 ligan terbaik serta pembanding sintesis flavopiridol, abemaciclib, ribociclib, dan palbociclib setelah dilakukan proses docking. Pada ligan sintesis pembanding yang memang sudah digunakan sebagai inhibitor CDK4 generasi pertama pada terapi penyakit kanker, flavopiridol memiliki interaksi ikatan hidrogen sebanyak 5 ikatan dan 13 interaksi hidrofobik (Gambar 5). Ikatan hidrogen pada flavopiridol terdiri dari 2 tipe yaitu 3 ikatan hidrogen konvensional dan 2 ikatan hidrogen karbon dimana ikatan hidrogen konvensional jauh lebih kuat dibandingkan dengan ikatan hidrogen karbon. Interaksi hidrofobik yaitu sebanyak 13 interaksi yaitu tipe interaksi pi-alkil sebanyak 9 interaksi dan tipe alkil-alkil sebanyak 4 interaksi. Dapat disimpulkan bahwa interaksi antara flavopiridol dengan reseptor lebih didominasi oleh interaksi hidrofobik dibandingkan ikatan hidrogen.

Pada ligan sintesis pembanding lainnya seperti abemaciclib, ribociclib dan palbociclib yang memang masih digunakan sebagai inhibitor CDK4 pada terapi penyakit kanker, abemaciclib memiliki interaksi ikatan hidrogen sebanyak 3 ikatan, interaksi halogen sebanyak 2 dan 15 interaksi hidrofobik (Gambar 6). Ikatan hydrogen pada abemaciclib terdiri dari 2 tipe yaitu 2 ikatan hidrogen konvensional dan 1 ikatan hidrogen karbon dimana ikatan hidrogen konvensional jauh lebih kuat dibandingkan dengan ikatan hidrogen karbon. Interaksi hdrofobik yaitu sebanyak 15 interaksi yaitu tipe interaksi pi-alkil sebanyak 5 interaksi, tipe alkil-alkil sebanyak 7 interaksi, tipe pi-sigma sebanyak 1 interaksi, tipe pi-pi sebanyak 1 interaksi. Dapat disimpulkan bahwa interaksi antara abemaciclib dengan reseptor lebih didominasi oleh interaksi hidrofobik dibandingkan ikatan hidrogen. Begitu juga dengan ribociclib (Gambar 7) dan Palbociclib (Gambar 8) yang juga didominasi oleh interaksi hidrofobik dibandingkan oleh ikatan hidrogen. Bila dilihat struktur senyawa abemaciclib, Ribociclib dan Palbociclib lebih dominan dengan struktur yang bersifat nonpolar seperti senyawa aromatis, karbon siklik sehingga senyawa-senyawa tersebut memiliki skor ChemPLP yang sangat rendah dibandingkan senyawa bahan alam karena distabilkan oleh interaksi hidrofobik.

Senyawa bahan alam Naringin memiliki interaksi yang lebih banyak dibandingkan dengan senyawa bahan alam apigenin dan epigallocatechin-3-gallat. Dapat dilihat pada 
Gambar 10 bahwa Naringin interaksi sebanyak 24 interaksi dengan interaksi ikatan hidrogen sebanyak 15 ikatan yang terdiri dari tipe ikatan hidrogen convensional sebanyak 8 ikatan, tipe ikatan hidrogen karbon sebanyak 6 ikatan dan tipe ikatan hidrogen tipe pi-donor sebanyak 1 ikatan. Interaksi hidrofobik pada naringin terdiri dari 9 interaksi dengan tipe interaksi dengan alkil sebanyak 1 interaksi dan tipe interaksi pi-alkil sebanyak 8 interaksi, Apigenin (Gambar 11) memiliki interaksi sebanyak 14 interaksi dengan interaksi ikatan hidrogen sebanyak 5 ikatan dengani tipe ikatan hidrogen convensional sebanyak 5 ikatan. Interaksi hidrofobik pada Apigenin terdiri dari 9 interaksi dengan tipe interaksi dengan pi-sigma sebanyak 1 interaksi dan tipe interaksi pi-alkil sebanyak 8 interaksi. Untuk interaksi pada Epigallocatechin-3gallate (Gambar 9) memiliki interaksi sebanyak 9 interaksi dengan interaksi ikatan hidrogen sebanyak 5 ikatan yang terdiri dari tipe ikatan hidrogen convensional sebanyak 4 ikatan dan tipe ikatan hidrogen karbon sebanyak 1 ikatan. Interaksi hidrofobik pada Epigallocatechin-3gallate terdiri dari 3 interaksi dengan tipe interaksi dengan alkil sebanyak 1 interaksi dan tipe interaksi pi-alkil sebanyak 2 interaksi. Pada epigallocatechin-3-gallate juga terdapat interaksi elektrostatik tipe pi-anion sebanyak 1 interaksi. Dapat disimpulkan untuk senyawa bahan alam Naringin memiliki afinitas yang paling baik karena memiliki banyak interaksi dibanding senyawa lainnya. Hal ini disebabkan karena senyawa Naringin banyak distabilkan oleh ikatan hidrogen convensional yang bersifat lebih kuat dibandingkan dengan ikatan hidrogen tipe lainnya karena pada struktur senyawa Naringin memiliki gugus-gugus yang bersifat elektronegatif untuk membentuk ikatan hidrogen convensional. Jarak ikatan hidrogen pada Naringin pun sudah memenuhi syarat yaitu jarak berkisar antara 2,5-3,5 $\AA$ (Syahputra et al., 2014).
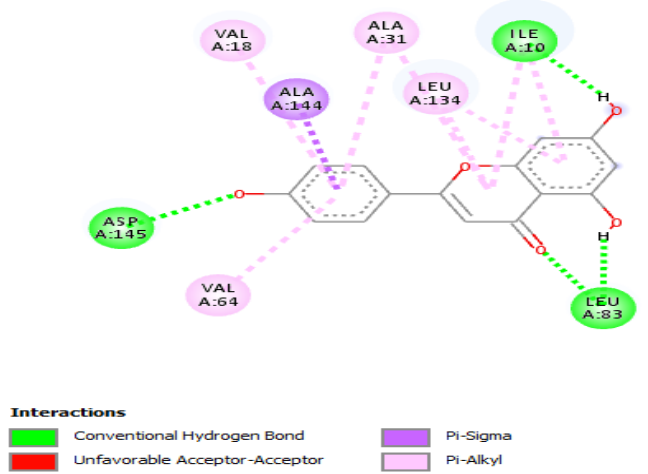

Gambar 11. Visualisasi interaksi senyawa apigenin

Bila dibandingkan dengan kompleks senyawa sintesis pembanding seperti abemaciclib, ribociclib, dan palbociclib, maka senyawa-senyawa pembanding tersebut distabilkan oleh interaksi hidrofobik. Hal ini disebabkan meningkatnya derajat ketidakaturan air dapat meningkatkan entropi yang berakibat pada menurunnya energi bebas yang menstabilkan kompleks ligan-reseptor. Stabilisasi yang dilakukan untuk menjaga stabilitas kompleks obatreseptor akibat menurunnya energi bebas kompleks obat-reseptor, sehingga oleh adanya interaksi hidrofobik maka skor CHEMPLP abemaciclib, ribociclib, dan palbociclib menjadi yang paling rendah. Sedangkan senyawa bahan alam naringin yang hanya distabilkan oleh 
dominasi ikatan hidrogen dibandingkan dengan interaksi hidrofobik. Bila dibandingkan dengan interaksi abemaciclib, ribociclib, dan palbociclib, skor CHEMPLP naringin masih jauh lebih besar namun masih lebih rendah dan lebih baik afinitasnya dibandingkan dengan Flavopiridol sebagai inhibitor CDK4 generasi pertama.

\section{KESIMPULAN}

Validasi metode protokol skrining terhadap struktur CDK2 mirip CDK4 secara internal yang dapat diterima yaitu reseptor $1 \mathrm{GIH}$ dengan ligand native 1PU dan RMSD 0,8072 $\AA$. Virtual skrining dan analisis dari senyawa bahan alam yang memiliki skor CHEMPLP terendah yaitu Naringin dengan skor CHEMPLP sebesar $-94,1781 \mathrm{Kkal} / \mathrm{mol}$ yang jauh lebih baik dibandingkan senyawa pembanding Flavopiridol namun masih lebih baik senyawa pembanding Abemaciclib, Ribociclib dan Palbociclib. Interaksi ligand-reseptor pada naringin lebih didominasi oleh ikatan Hidrogen dibandingkan dengan senyawa pembanding abemaciclib, ribociclib dan palbociclib yang didominasi oleh interaksi hidrofobik, sehingga naringin berpotensi sebagai inhibitor CDK4 sebagai antiproliferasi sel kanker.

\section{DAFTAR PUSTAKA}

Adelina R. 2014, Uji Molecular Docking Annomuricin E dan Muricapentocin pada Aktivitas Antiproliferasi (Molecular Docking Studies of Annomuricin E and Muricapentocin on Antiproliferation Activity ). Jurnal Ilmu Kefarmasian Indonesia. 12(1): 32-36.

Arba, M., Ardiansyah, R., \& Leonita, M. 2016, Studi Hubungan Kuantitatif Struktur-Aktivitas Senyawa Turunan Mesoindigo Sebagai Inhibitor CDK4. Journal Kimia Riset, 1(2), 129136.

Bailon-Moscoso, N., Cevallos-Solorzano, G., Romero-Benavides, J. C., Isabel, M., \& Orellana, R. 2017, Natural Compounds as Modulators of Cell Cycle Arrest: Application for Anticancer Chemotherapies. Current Genomics, 18(2), 106-131. https://doi.org/10.2174/138920291766616080812

Corona, S. P., \& Generali, D. 2018, Abemaciclib : a CDK4 / 6 inhibitor for the treatment of HR + / HER2 - advanced breast cancer. Drug Design, Development and Therapy, 12, $321-330$.

Ganatra, S. H., \& Suchak, A. S. 2012, Inhibition Studies of Terpene Based Natural Products with Cyclin-Dependent Kinase 4 (CDK4 Mimic CDK2). International Journal of Pharmaceutical Sciences and Research, 3(9), 3196-3203.

Ikuta, M., Kamata, K., Fukasawa, K., Honma, T., Machida, T., Hirai, H., Nishimura, S. 2001, Crystallographic Approach to Identification of Cyclin-Dependent Kinase 4 (CDK4)Spesific Inhibitors by Using CDK4 mimic CDK2 Protein. Journal of Biology Chemistry, 276(29), 27548-27554.

Kemenkes. 2015, Summary for Policymakers. (Intergovernmental Panel on Climate Change, Ed.), Climate Change 2013 - The Physical Science Basis. Cambridge: Cambridge 
University Press. https://doi.org/10.1017/CBO9781107415324.004

Mas'ula, Y., \& Kusuma, A. S. W. 2018, Aktivitas Antikanker Tanaman Rumput Lidah Ular (Hedyotis difussa Willd.). Farmaka, 15(3), 17-23.

Mukesh, B., \& Rakesh, K. 2011, Molecular Docking: A Review. International Journal of Research in Ayurveda \& Pharmacy, 2(6), 1746-1751.

Mumpuni, B., Widarsa A., Susilawati Y., Oisan, Nurrochmad A., Pranowo HD., Jenie UA., Istyastono EP. 2014, Konstruksi dan Validasi Protokol Skrining Virtual Berbasis Struktur dengan Kode PDB 3MQE, 3NTG, dan 3LN0 untuk Penemuan Inhibitor Siklooksigenase-2 (COX-2). Jurnal Ilmu Kefarmasian Indonesia, 12(1), 117-123.

Pandrangi, A. 2014, Molecular Docking and QSAR Studies on CDK4 Inhibitors Using In Silico Techniques. Journal of Pharmaceutical and Scientific Innovation, 3(2), 164-169.

Purnomo, H. 2013, Kimia Komputasi Uji In Silico Senyawa Anti Kanker. Yogyakarta: Pustaka Pelajar.

Rollando. 2017, Pengantar Kimia Medisinal. (S. R. Wicaksono, Ed.) (Pertama). Malang- Jawa Timur: CV. Seribu Bintang.

Shafiq, M. I., Steinbrecher, T., \& Schmid, R. 2012, FASCAPLYSIN as a Specific Inhibitor for CDK4: Insights from Molecular Modelling. PLOS ONE, 7(8), 1-9. https://doi.org/10.1371/journal.pone.0042612

Sherr, C. J., Beach, D., \& Shapiro, G. I. 2016, Targeting CDK4 and CDK6 : From Discovery

to Therapy. Cancer Discovery, 1(April), 353-368. https://doi.org/10.1158/2159-8290.CD-150894

Stryer, L. 1996, Biokimia Volume 1 Edisi 4. Buku Kedokteran EGC. Jakarta: Buku Kedokteran EGC.

Syahputra G, Ambarsari L, Sumaryada T. 2014, Simulasi Docking Senyawa Kurkumin dan Analognya Sebagai Inhibitor Enzim 12-Lipoksigenase. Jurnal Biofisika. 10(1) : 55-67.

Vermeulen, K., Berneman, Z.N., and Van Bockstaele, D.R. (2003), Cell Cycle and Apoptosis. Cell Proliferation, 36(3), 165-175.

Wang, L., \& Ren, D. M. 2010, Flavopiridol, the First Cyclin-Dependent Kinase Inhibitor: Recent Advances in Combination Chemotherapy. Mini-Reviews in Medical Chemistry, 10, 1058-1070. https://doi.org/10.2174/1389557511009011058

Yanuar, A. 2012, Praktek dan Aplikasi pada Virtual Screening. Depok: UI Press. 